\title{
Improved performances of lithium disilicate glass-ceramics by seed induced crystallization
}

\author{
Ting ZHAO ${ }^{a}$, Mei-Mei LIAN ${ }^{a}$, Yi QIN ${ }^{a, *}$, Jian-Feng ZHU, \\ Xin-Gang $\mathrm{KONG}^{a}$, Jian-Feng $\mathrm{YANG}^{b}$ \\ ${ }^{a}$ School of Materials Science and Engineering, Shaanxi Key Laboratory of Green Preparation and \\ Functionalization for Inorganic Materials, Shaanxi University of Science and Technology, Xi'an 710021, China \\ ${ }^{b}$ State Key Laboratory for Mechanical Behavior of Materials, Xi'an Jiaotong University, Xi'an 710049, China
}

Received: July 25, 2020; Revised: January 22, 2021; Accepted: January 22, 2021

(C) The Author(s) 2021.

\begin{abstract}
Self-reinforced lithium disilicate $\left(\mathrm{Li}_{2} \mathrm{Si}_{2} \mathrm{O}_{5}, \mathrm{LD}\right)$ glass-ceramics were hot pressing sintered by introducing $5 \mathrm{wt} \% \quad \mathrm{Li}_{2} \mathrm{Si}_{2} \mathrm{O}_{5}$ crystal seeds into two different glass compositions of $\mathrm{SiO}_{2}-\mathrm{Li}_{2} \mathrm{O}-\mathrm{P}_{2} \mathrm{O}_{5}-\mathrm{ZrO}_{2}-\mathrm{Al}_{2} \mathrm{O}_{3}-\mathrm{K}_{2} \mathrm{O}-\mathrm{La}_{2} \mathrm{O}_{3}$ (7C LD) and $\mathrm{SiO}_{2}-\mathrm{Li}_{2} \mathrm{O}-\mathrm{K}_{2} \mathrm{O}-\mathrm{La}_{2} \mathrm{O}_{3}$ (4C LD). The results show that the seeds play an important role in the crystallization inducement, and microstructural and property improvement of the glass, especially for the glass powder without the nucleating agent of $\mathrm{P}_{2} \mathrm{O}_{5}$. The microstructure features a wider bimodal grain size distribution with large rod-like crystals epitaxially grown along the seeds and small crystals nucleated from the glass powder itself, contributing to the improvement of the performance especially the fracture toughness. The specimen of $4 \mathrm{C} \mathrm{LD}$ glass with the addition of $5 \mathrm{wt} \% \mathrm{Li}_{2} \mathrm{Si}_{2} \mathrm{O}_{5}$ seeds exhibited the best

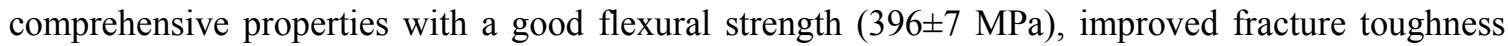
$\left(3.31 \pm 0.19 \mathrm{MPa} \cdot \mathrm{m}^{1 / 2}\right)$, and comparable translucency as IPS e.max. This research provides a new idea and method for the improvement of the fracture toughness of lithium disilicate glass-ceramics without affecting its aesthetic appearance, and lays the foundation for its clinical applications.
\end{abstract}

Keywords: lithium disilicate (LD); seeds; mechanical properties; translucency

\section{Introduction}

Lithium disilicate $\left(\mathrm{Li}_{2} \mathrm{Si}_{2} \mathrm{O}_{5}, \mathrm{LD}\right)$ glass-ceramics, as a new kind of dental restorative materials, have many incomparable advantages with the traditional metal materials, macromolecule materials and ceramics, such as high mechanical properties (flexural strength $\sim 300$ $400 \mathrm{MPa}$ ), comparable wear resistance, aesthetical characteristics as natural teeth, good machinability, and

* Corresponding author.

E-mail: qinyi@sust.edu.cn so on [1-6], because of which they have gained increasing attention in the latest research. However, due to their intrinsic brittleness and low defect tolerance, the fracture toughness of $\mathrm{Li}_{2} \mathrm{Si}_{2} \mathrm{O}_{5}$ glass-ceramics is far less than that of zirconia, alumina, and other traditional ceramic restorations [7-9]. Therefore, how to improve the fracture toughness on the basis of maintaining good aesthetics has become an urgent research topic, which has a very important practical significance for their large-scale application in the field of dental restoration.

However, only a few studies have discussed the toughening of lithium disilicate glass-ceramics. The 
most common method is to introduce zirconia into the glass composition. By using its transformation toughening effect [10-12], glass-ceramics can be reinforced [13,14]. Huang et al. [10] successfully prepared t-Z $\mathrm{rO}_{2}$ (3Y-TZP) toughened lithium disilicate glass-ceramics by vacuum hot-pressing sintering, with the highest strength of $340 \mathrm{MPa}$ and fracture toughness of $3.50 \mathrm{MPa} \cdot \mathrm{m}^{1 / 2}$. However, the addition of zirconia also had some adverse effects such as the difficulty of uniform distribution and the obstacle to densification, making the porosity as high as $1.90 \%$. Also other second phases such as whisker, $\mathrm{SiC}$ nanowire, alumina, carbon fiber were involved to toughen glass-ceramics [15-19]. Although the toughening mechanisms of heterogeneous phase transformation, crack deflection, crack bridging, and pull-out effect were analyzed [20], the effects of these toughening measures on the translucency of glassceramics were not explicitly mentioned. In addition, the introduction of heterogeneous toughening phases has some problems, such as difficulty in densification and the matrix powder cannot fill the fiber skeleton uniformly without damaging the fibers. It will inevitably lead to strong light scattering and refraction caused by non-uniformly dispersed second phase, heterogeneous interface, and mismatch of the refractive index, which will decrease the translucency of lithium disilicate glass-ceramics and make them difficult to match the appearance of natural teeth.

Considering the shortcomings of the toughening by heterogeneous phases mentioned above, and the fact that $\mathrm{Li}_{2} \mathrm{Si}_{2} \mathrm{O}_{5}$ crystalline phase and its glass phase have nearly the same refractive index [21], many researchers tried to improve the fracture toughness and translucency of $\mathrm{Li}_{2} \mathrm{Si}_{2} \mathrm{O}_{5}$ glass-ceramics by using different nucleating agents and changing the heat treatment processes (casting, sintering, etc.) [22-29]. However, the effect is not satisfactory. The reason is that no matter the overall crystallization (melting method) or surface crystallization (powder sintering method) applied, all the crystalline phases are from the crystallization of parent glass. The nucleation number is very large so the precipited $\mathrm{Li}_{2} \mathrm{Si}_{2} \mathrm{O}_{5}$ crystals usually display small grain size with a narrow size distribution, which form more interfacial area with the glass matrix [23,27,30,31]. These interfaces not only easily generate more flaws acting as a cracking source, but also shorten the crack propagation path, limiting the improvement of fracture toughness [32]. At the same time, many small interfaces cannot effectively reduce the scattering and refraction of visible light, making the translucency poor. Therefore, for the homogeneous toughening of lithium disilicate glass-ceramics, it is necessary to control the number of nucleation sites and the size of crystals, that is, crystallization controllable.

In our previous studies [33,34], the coexistence of large-sized rod-like $\mathrm{Li}_{2} \mathrm{Si}_{2} \mathrm{O}_{5}$ crystals and small-sized ones formed by solid state reaction of $\mathrm{Li}_{2} \mathrm{SiO}_{3}$ (LM) crystal and $\mathrm{SiO}_{2}$ glass can effectively improve mechanics performance, especially the fracture toughness of $\mathrm{Li}_{2} \mathrm{Si}_{2} \mathrm{O}_{5}$ glass-ceramics. Seed toughening is one of the most effective methods to obtain this kind of microstructure and it has been widely used in traditional ceramic materials such as $\mathrm{Si}_{3} \mathrm{~N}_{4}[35,36], \mathrm{Al}_{2} \mathrm{O}_{3}$ [37], and SiAlON [38]. It is known that the so-called in-situ growth is to make some grains grow into elongated grains with high aspect ratio by controlling the sintering process, thus obtaining the microstructure similar to that of fiber or whisker reinforced composites [39]. This microstructure with a bimodal grain size distribution can play a good role in deflection and bridging cracks to improve the fracture toughness and strength of materials, while basically not affecting other properties [40,41].

However, few reports concerning the seed toughening in glass-ceramics have been mentioned. In this paper, $\mathrm{Li}_{2} \mathrm{Si}_{2} \mathrm{O}_{5}$ seeds were added to different glass compositions to induce crystallization and help crystals epitaxially grow to large-sized rod-like grains, while the parent glass powders with high surface energy precipitate small-sized rod-like crystals through spontaneous surface nucleation, thus forming the coexistence of multi-scale crystals, as shown in Fig. 1. The effects of $\mathrm{Li}_{2} \mathrm{Si}_{2} \mathrm{O}_{5}$ seeds on the microstructure, mechanical properties, and translucency characteristics of lithium disilicate glass-ceramics were also discussed. We believe that marrying the very good aesthetics with good mechanical properties may help open the area of restorative application of $\mathrm{Li}_{2} \mathrm{Si}_{2} \mathrm{O}_{5}$ glass-ceramics, and provide a new way for preparing toughened glass-ceramics.

\section{Materials and methods}

\section{1 Synthesis of rod-like $\mathrm{Li}_{2} \mathrm{Si}_{2} \mathrm{O}_{5}$ seeds}

99.9\% purity $\mathrm{Li}_{2} \mathrm{CO}_{3}$ powder and $\mathrm{SiO}_{2}$ powder were used as the starting materials, and $\mathrm{Li}_{2} \mathrm{Si}_{2} \mathrm{O}_{5}$ seeds were solid-state-reaction synthesized according to the following reaction:

$$
\mathrm{Li}_{2} \mathrm{CO}_{3}+2 \mathrm{SiO}_{2}=\mathrm{Li}_{2} \mathrm{Si}_{2} \mathrm{O}_{5}+\mathrm{CO}_{2}
$$




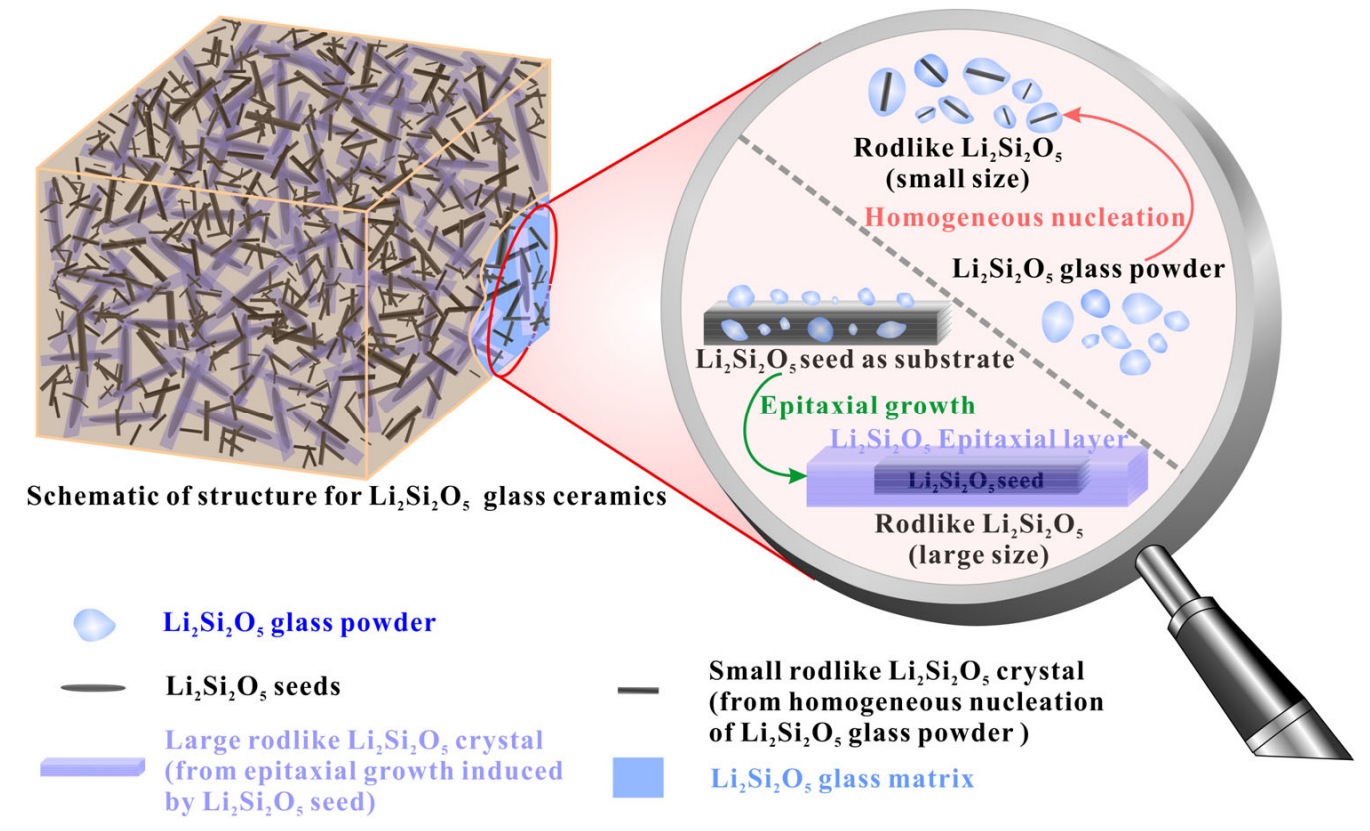

Fig. 1 Microstructure design of the seed-toughening lithium disilicate glass-ceramics.

The mixture of $\mathrm{Li}_{2} \mathrm{CO}_{3}$ and $\mathrm{SiO}_{2}$ in molar ratio of $1: 2$ was ball-milled for $5 \mathrm{~h}$ and dried by using a rotatory evaporator. Then the powders were placed in a corundum crucible and underwent a two-step heat treatment in an electric furnace. The mixture was firstly heated at $710{ }^{\circ} \mathrm{C}$ for $2 \mathrm{~h}$, and then the temperature was raised to $980{ }^{\circ} \mathrm{C}$ for $4 \mathrm{~h}$ at a heating rate of $3{ }^{\circ} \mathrm{C} \cdot \mathrm{min}^{-1}$. After that, the heated powders were milled, dispersed, and acid washed at $1 \mathrm{vol} \% \mathrm{HF}$ to remove the residual glass phase.

\section{2 Preparation of $\mathrm{Li}_{2} \mathrm{Si}_{2} \mathrm{O}_{5}$ glass-ceramics}

In order to explore the controlled crystallization effect of seeds on different glass compositions, two kinds of $\mathrm{Li}_{2} \mathrm{Si}_{2} \mathrm{O}_{5}$ glass powders were prepared and the compositions are shown in Table 1. They have the same molar ratio of $\mathrm{SiO}_{2}: \mathrm{Li}_{2} \mathrm{O}=2.39: 1$ to ensure that the main crystalline phase is $\mathrm{Li}_{2} \mathrm{Si}_{2} \mathrm{O}_{5}[42,43]$. Besides that, $4 \mathrm{C}$ LD glass only contains $\mathrm{K}_{2} \mathrm{O}$ to promote the glass melting process [44] and $\mathrm{La}_{2} \mathrm{O}_{3}$ to decrease the viscosity of the glass [45], while removing the nucleating agent of $\mathrm{P}_{2} \mathrm{O}_{5}$ compared with $7 \mathrm{C}$ LD glass. As for the 7C LD composition, the addition of $\mathrm{ZrO}_{2}$ can enhance the polymerization of the silicate network and significantly increase the mechanical strength values as well as the translucent properties of the glass-ceramics $[46,47]$. And $\mathrm{Al}_{2} \mathrm{O}_{3}$ may simultaneously suppress the immiscibility temperature while raising the $T_{\mathrm{g}}$ of experimental glasses, resulting in the improved densification, mechanical
Table 1 Compositions of $\mathrm{Li}_{2} \mathrm{Si}_{2} \mathrm{O}_{5}$ glass

\begin{tabular}{cccccccc}
\hline & & & & & & \multicolumn{3}{c}{ (Unit: mol\%) } \\
\hline 7C LD & 27.6 & 66.0 & 0.8 & 1.4 & 1.8 & 1.8 & 0.6 \\
$4 \mathrm{C} \mathrm{LD}$ & 28.6 & 68.6 & - & - & - & 2.0 & 0.8 \\
\hline
\end{tabular}

strength, and chemical durability $[48,49]$. Reagent grade powders of $\mathrm{Li}_{2} \mathrm{CO}_{3}, \mathrm{SiO}_{2}, \mathrm{NH}_{4} \mathrm{H}_{2} \mathrm{PO}_{4}, \mathrm{ZrO}_{2}, \mathrm{Al}_{2} \mathrm{O}_{3}$, $\mathrm{K}_{2} \mathrm{CO}_{3}$, and $\mathrm{La}_{2} \mathrm{O}_{3}$ were used as the raw materials. After mixing, melting (at $1450{ }^{\circ} \mathrm{C}$ for $2 \mathrm{~h}$ ), quenching, and ball-milling $(10 \mathrm{~h}$, with high purity zirconia balls in an ethanol environment), the glass powders with $D_{50}$ value of $\sim 5 \mu \mathrm{m}$ were obtained. The detailed process is the same as our previous studies $[33,34]$.

The starting powder mixtures of $4 \mathrm{C}$ or $7 \mathrm{C} \mathrm{LD} \mathrm{glass}$ without and with $5 \mathrm{wt} \% \mathrm{Li}_{2} \mathrm{Si}_{2} \mathrm{O}_{5}$ seeds $(4 \mathrm{C}, 4 \mathrm{C} 5 \mathrm{~S}, 7 \mathrm{C}$, and $7 \mathrm{C} 5 \mathrm{~S}$ ) were wet mixed with $\mathrm{ZrO}_{2}$ balls in anhydrous alcohol for $2 \mathrm{~h}$. The slurry was dried, uniaxially pressed (30 MPa in a hardened steel die, $\Phi 30 \mathrm{~mm} \times 10 \mathrm{~mm}$ ), and presintered in a furnace (SN33810297, DeguDent GmbH, Germany) at $800{ }^{\circ} \mathrm{C}$ for $20 \mathrm{~min}$. After that, the middle compacts were hot-pressing sintered in a vacuum furnace at $850{ }^{\circ} \mathrm{C}$ for $0.5 \mathrm{~h}$ under a pressure of $30 \mathrm{MPa}$. Finally, after cooling down to ambient temperature, the surface layers of the samples were removed.

\section{3 Characterization}

The chemical compositions of $4 \mathrm{C}$ and $7 \mathrm{C}$ LD glass 
powders were analyzed by X-ray fluorescence (XRF, S4Pioneer, Bruker, Germany). To evaluate the densification degree, the bulk density was measured by using Archimedes method and from that the relative density was calculated. Three samples were estimated to get the mean value. Crystalline phases were identified by X-ray diffraction analysis (XRD, D/MAX-RA, Rigaku, Japan) with $\mathrm{Cu} \mathrm{K} \alpha$ radiation and scanning from $10^{\circ}$ to $70^{\circ}$. The sampling interval was $0.02^{\circ} 2 \theta$. The quantitative phase analysis was conducted by Rietveld refinements, using MAUD software [50]. A Delf line broadening model and an isotropic size-strain model were used. For any analysis, the most important parameters of $R_{\mathrm{w}}$ and sig were minimized to less than $15 \%$ and 2 , respectively. The entire suite of datasets was refined sequentially, and the crystallinities were obtained.

Electron backscatter diffraction (EBSD, Phenom Pro-X, the Netherlands) and field emission scanning electron microscope (FESEM, S-4800, Hitachi, Tokyo, Japan) were used to characterize the microstructures and phases of the unetched and etched samples ( $5 \mathrm{vol} \%$ HF for $1 \mathrm{~min}$ ), respectively. The grain size was counted and analyzed. More than 200 grains were chosen for each sample. Transmission electron microscopy (TEM) and selected area electron diffraction (SAED) investigations were performed using a JEM 200CX microscope with $120 \mathrm{kV}$ electron beam. For the preparation of TEM specimen, the disc specimens were first ground to about $20 \mu \mathrm{m}$ thick, then polished and followed by ion beam thinning (Gatan Model 691 PIPS).

Rectangular bars $(3 \mathrm{~mm} \times 4 \mathrm{~mm} \times 20 \mathrm{~mm}$, after polishing) were used to determine the three-point flexural strength with a span of $16 \mathrm{~mm}$ at a cross-head speed of $0.5 \mathrm{~mm} / \mathrm{min}$ by the universal testing machine (INSTRON1195, UK). For the fracture toughness measurement, the samples $(3 \mathrm{~mm} \times 4 \mathrm{~mm} \times 20 \mathrm{~mm})$ with a V-notch depth of $0.8-1.2 \mathrm{~mm}$ and the single edge V-notched beam (SEVNB) testing method were used. The fracture toughness was calculated according to the international standard ISO 6872 . The average flexural strength and fracture toughness were obtained from five samples and three specimens, respectively. For the determination of optical properties, the required fine surface and uniform thickness (0.8 $\mathrm{mm}$ in thickness) of the specimens were obtained by polishing with wet silicon carbide papers. Translucent characteristics of the final glass-ceramics were evaluated in term of contrast ratio (CR) [21], which is defined as the ratio of illuminance of the material when it is placed over a black background to the illuminance of the same material when it is placed over a white background. Illuminance values were tested using a colorimeter and $\mathrm{CR}$ values were calculated, which is 0 for a transparent material and 1 for a totally opaque material.

\section{Results}

\section{1 Characterization of $\mathrm{Li}_{2} \mathrm{Si}_{2} \mathrm{O}_{5}$ seeds and the glass powders}

Figures 2(a) and 2(b) show the SEM images and XRD patterns of the $\mathrm{Li}_{2} \mathrm{Si}_{2} \mathrm{O}_{5}$ seeds synthesized by solid-state reaction. In Fig. 2(a), the seeds are rod-like crystals with a length of 1.2-6.5 $\mu \mathrm{m}$ and a width of $0.1-1.0 \mu \mathrm{m}$. The average length is $\sim 2 \mu \mathrm{m}$ and the aspect ratio of the seeds is 3-6. The XRD analysis in Fig. 2(b) indicated the existence of $\mathrm{Li}_{2} \mathrm{Si}_{2} \mathrm{O}_{5}$ crystalline phase and no other secondary phase, confirming the reaction of $\mathrm{Li}_{2} \mathrm{CO}_{3}$ and $\mathrm{SiO}_{2}$ is complete. And most of the glass phases were removed after acid rinse treatments. Thus, the synthesized high-quality $\mathrm{Li}_{2} \mathrm{Si}_{2} \mathrm{O}_{5}$ seeds lay a foundation for the successful preparation of the self-toughed
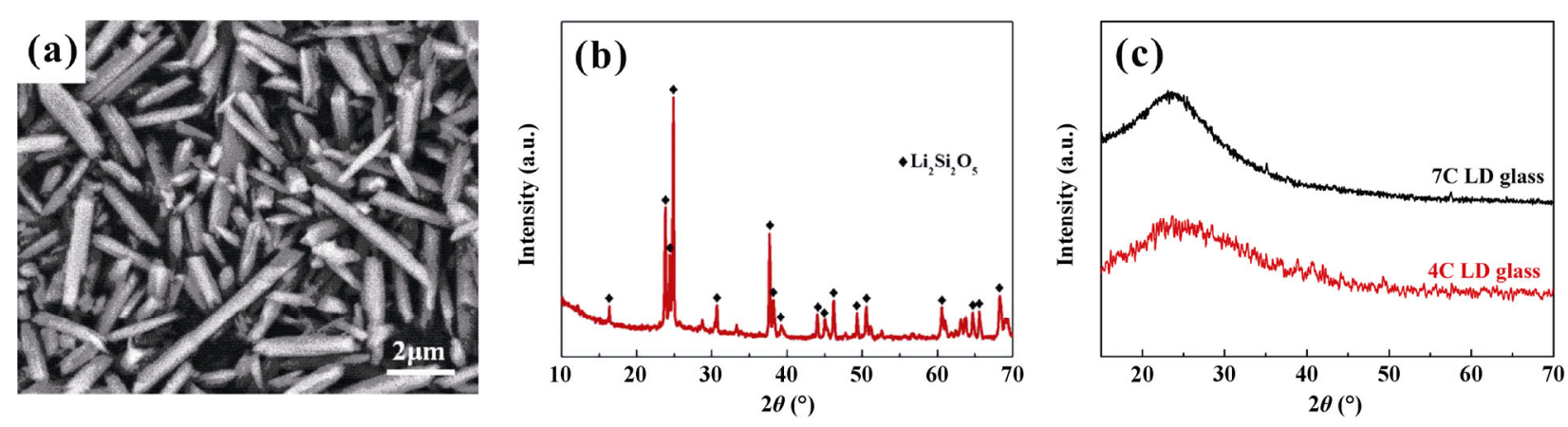

Fig. 2 (a) SEM image and (b) XRD pattern of the $\mathrm{Li}_{2} \mathrm{Si}_{2} \mathrm{O}_{5}$ seeds synthesized by solid-state reaction; (c) XRD patterns of the $4 \mathrm{C}$ and $7 \mathrm{C} \mathrm{LD}$ glass powders. 
$\mathrm{Li}_{2} \mathrm{Si}_{2} \mathrm{O}_{5}$ glass-ceramics microstructure with elongated grains. Crystalline phases of the two glass powders were identified by X-ray diffraction analysis before heating, and the results in Fig. 2(c) showed that the powders are in the amorphous status.

Table 2 shows the chemical compositions of the $4 \mathrm{C}$ and $7 \mathrm{C} \mathrm{LD}$ glass powders. It can be seen that in the $4 \mathrm{C}$ LD glass, besides the main components of $\mathrm{Li}$ (could not be detected), $\mathrm{O}, \mathrm{Si}, \mathrm{K}$, and $\mathrm{La}$, little $\mathrm{Al}$ was detected due to the introduction of alumina from stirring rods while other impurities were very few. The chemical composition of the 7C LD glass was almost the same besides the composed elements $\mathrm{Al}, \mathrm{P}$, and $\mathrm{Zr}$.

\section{2 Phase formation}

Figure 3 shows the XRD patterns and crystallinity of the $\mathrm{Li}_{2} \mathrm{Si}_{2} \mathrm{O}_{5}$ glass-ceramics from $4 \mathrm{C}$ and $7 \mathrm{C}$ LD glass powders without and with $5 \mathrm{wt} \% \mathrm{Li}_{2} \mathrm{Si}_{2} \mathrm{O}_{5}$ seeds. In Fig. 3(a), it can be found despite the difference in composition, the main crystalline phase of all the samples was only $\mathrm{Li}_{2} \mathrm{Si}_{2} \mathrm{O}_{5}$ (ICCD Card 01-040-0376). The intensity of the $\mathrm{Li}_{2} \mathrm{Si}_{2} \mathrm{O}_{5}$ diffraction peaks varied slightly, indicating the crystallinity changed. In Fig. 3(b), it can be seen that for the two kinds of glass powders with different composition, crystallinities of the samples were increased by $\sim 10 \%$ with the addition of $\mathrm{Li}_{2} \mathrm{Si}_{2} \mathrm{O}_{5}$ seeds $(5 \mathrm{wt} \%)$.

\section{3 Morphology}

Figure 4 shows the SEM morphologies of the etched
$\mathrm{Li}_{2} \mathrm{Si}_{2} \mathrm{O}_{5}$ glass-ceramics with different compositions. All the specimens showed a closely packed and multidirectionally interlocked microstructure of numerous rod-like $\mathrm{Li}_{2} \mathrm{Si}_{2} \mathrm{O}_{5}$ crystals protruding from the glass matrix. However, the crystal morphologies especially the grain sizes are quite different, and the statistical results are clearly shown in Table 3. It is found that the $\mathrm{Li}_{2} \mathrm{Si}_{2} \mathrm{O}_{5}$ crystals in $7 \mathrm{C}$ and $7 \mathrm{C} 5 \mathrm{~S}$ samples have smaller grain size but larger aspect ratio, making them typical long rod-like crystals. Another interesting phenomenon is that the grain size of $4 \mathrm{C}$ and $7 \mathrm{C}$ samples are more uniform and no larger grain is found. While in the seed addition samples of $4 \mathrm{C} 5 \mathrm{~S}$ and $7 \mathrm{C} 5 \mathrm{~S}$, some larger grains with high aspect ratio embedded in a smaller grained matrix was observed. It is consistent with the microstructural design (Fig. 1) that large rod-like crystals was believed to result from epitaxy growth of the $\mathrm{Li}_{2} \mathrm{Si}_{2} \mathrm{O}_{5}$ seeds while the small grains are grown from the spontaneous nucleation of the glass powders. The bimodal distribution morphology is more obvious in $4 \mathrm{C} 5 \mathrm{~S}$ so that the average grain size increased.

To further explore the variation of the grain size caused by the seed addition in different glass powders, the grain size distribution in length and width directions of the samples is statistical analyzed, as shown in Fig. 5. Compared to $7 \mathrm{C}$, the grain size of $7 \mathrm{C} 5 \mathrm{~S}$ sample increased slightly both in the direction of length and width and apparently a small number of large grains appeared. Nevertheless, the overall grain size distribution of 7C5S was still concentrated. By contrast, the grain size of $4 \mathrm{C} 5 \mathrm{~S}$ sample shows a much wider bimodal

Table 2 Chemical compositions of $4 \mathrm{C}$ and $7 \mathrm{C}$ LD glass powders analyzed by XRF

\begin{tabular}{|c|c|c|c|c|c|c|c|c|c|c|}
\hline \multirow{2}{*}{ Glass } & \multicolumn{10}{|c|}{ Composition (wt\%) } \\
\hline & $\mathrm{O}$ & $\mathrm{Si}$ & $\mathrm{La}$ & $\mathrm{K}$ & $\mathrm{Al}$ & $\mathrm{Zr}$ & $\mathrm{P}$ & $\mathrm{Ca}$ & $\mathrm{Cr}$ & $\mathrm{Fe}$ \\
\hline 4C LD & 57.8 & 32.9 & 4.62 & 3.51 & 1.03 & 0.0152 & - & 0.0172 & 0.0474 & 0.0441 \\
\hline 7C LD & 55.6 & 31.4 & 3.21 & 2.69 & 1.89 & 2.45 & 2.47 & 0.0087 & 0.0526 & 0.0401 \\
\hline
\end{tabular}
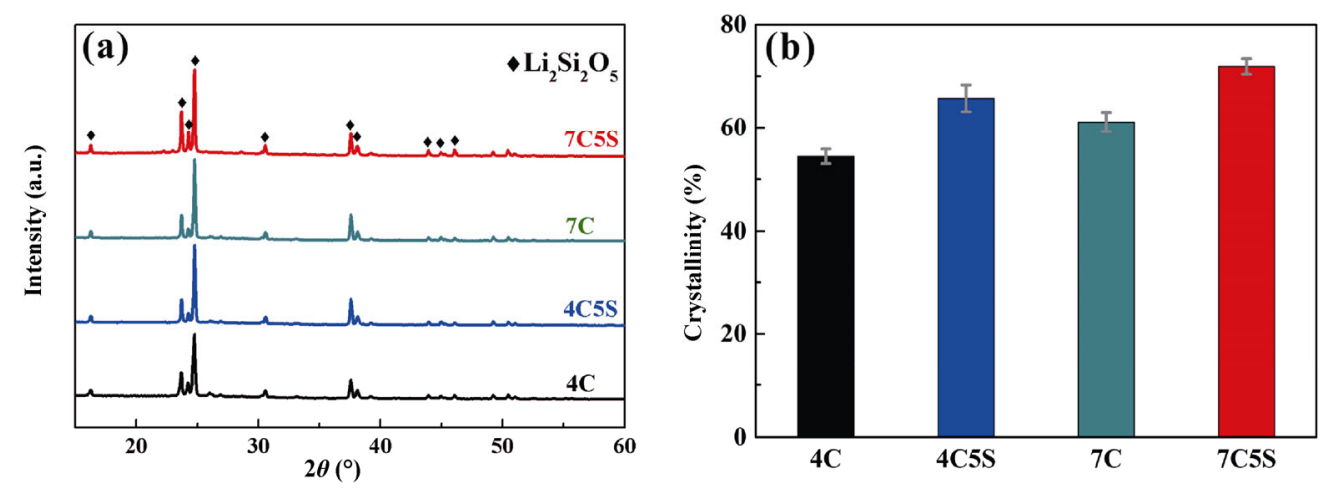

Fig. 3 (a) XRD patterns and (b) crystallinity of the $\mathrm{Li}_{2} \mathrm{Si}_{2} \mathrm{O}_{5}$ glass-ceramics with different compositions hot-pressed at $850{ }^{\circ} \mathrm{C}$ for $0.5 \mathrm{~h}$. 

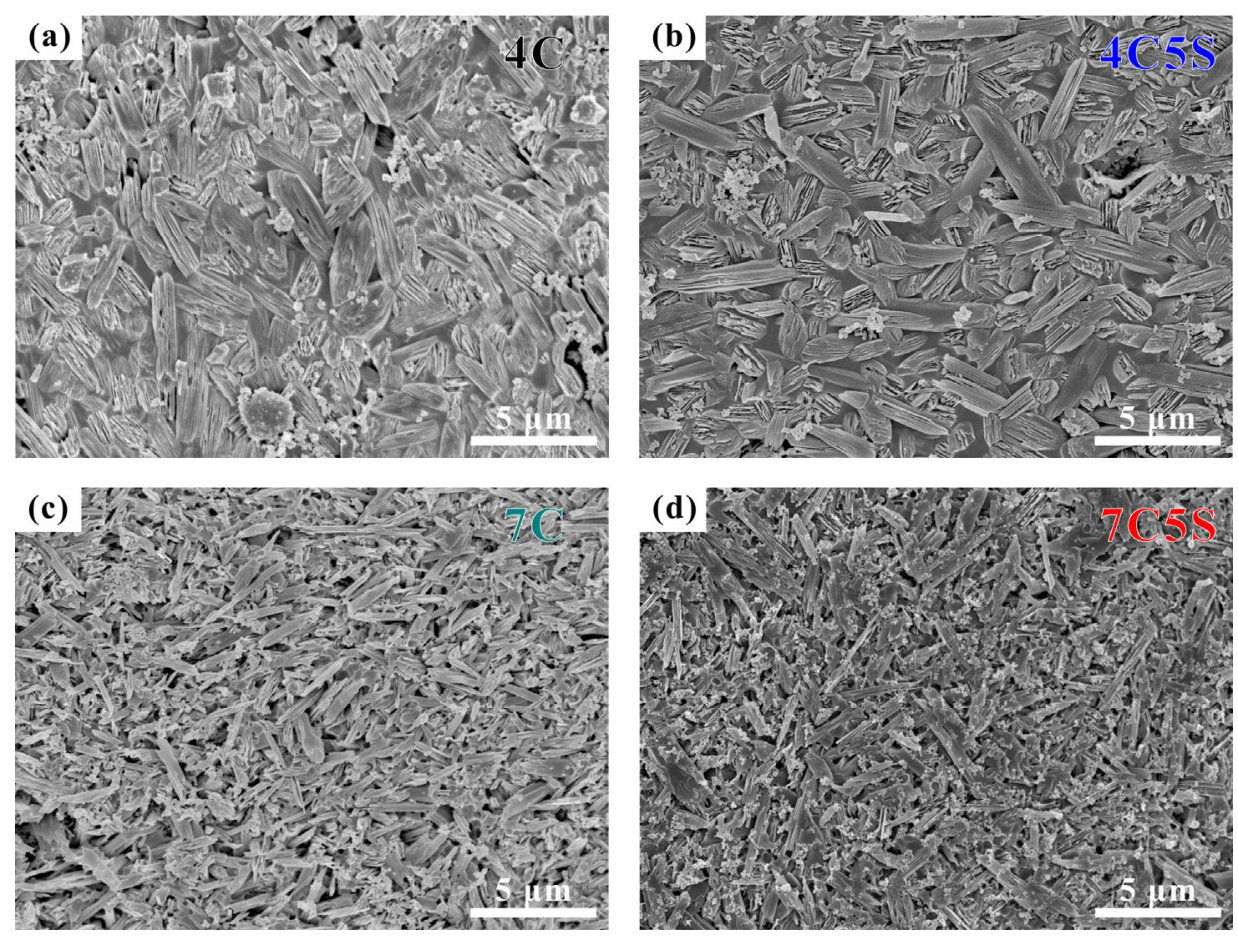

Fig. $4 \mathrm{SEM}$ images of the $\mathrm{Li}_{2} \mathrm{Si}_{2} \mathrm{O}_{5}$ glass-ceramics with different compositions hot-pressed at $850{ }^{\circ} \mathrm{C}$ for $0.5 \mathrm{~h}$ : (a) $4 \mathrm{C}$; (b) 4C5S; (c) 7C; (d) 7C5S.
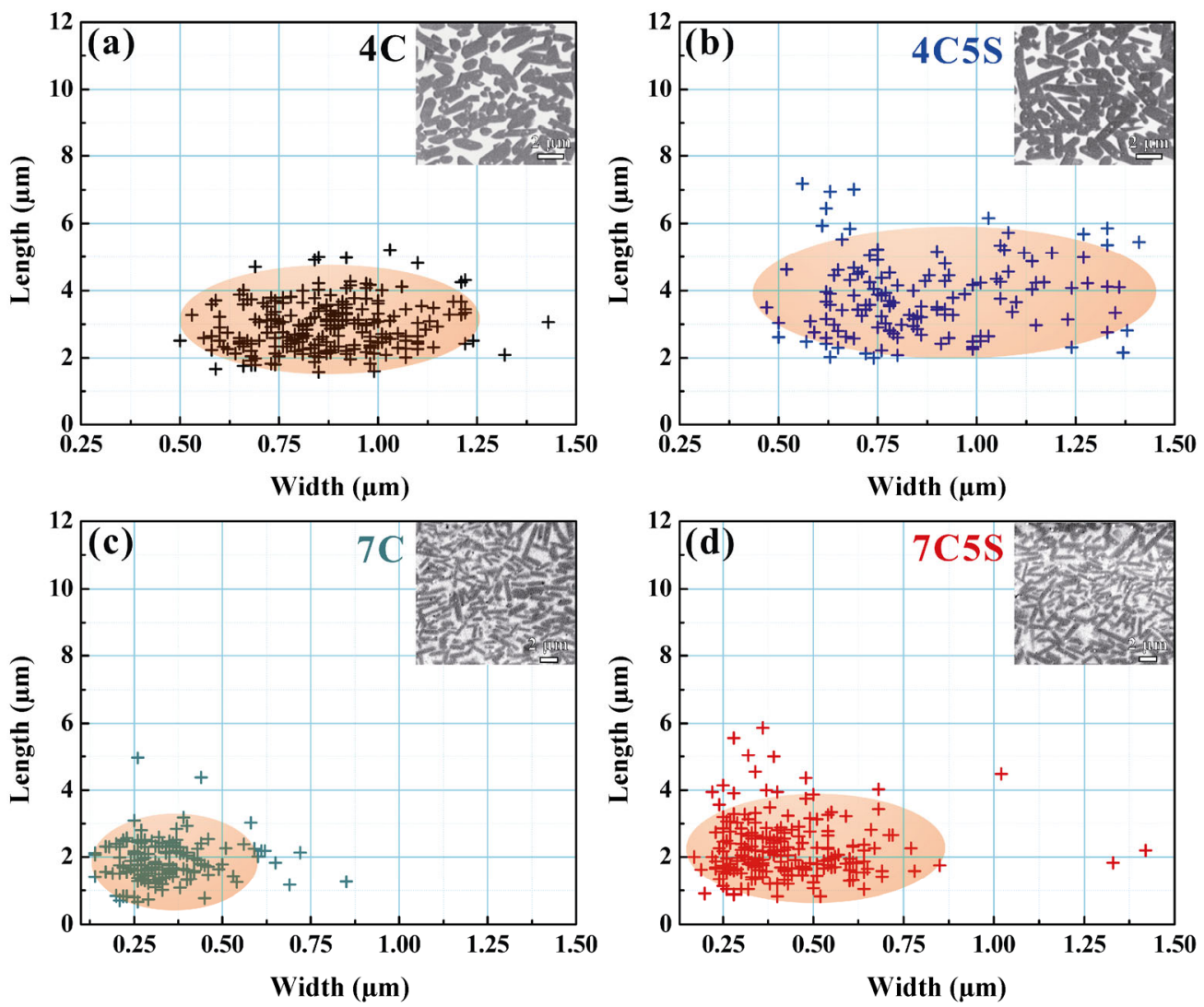

Fig. 5 Grain size distribution of the $\mathrm{Li}_{2} \mathrm{Si}_{2} \mathrm{O}_{5}$ glass-ceramics with different compositions hot-pressed at $850{ }^{\circ} \mathrm{C}$ for $0.5 \mathrm{~h}$ : (a) 4C; (b) 4C5S; (c) 7C; (d) 7C5S. The insets are the corresponding EBSD micrographs. 
Table 3 Average length $(\bar{L})$, width $(\bar{W})$, and aspect ratio $(\bar{R})$ of the $\mathrm{Li}_{2} \mathrm{Si}_{2} \mathrm{O}_{5}$ glass-ceramics with different compositions

\begin{tabular}{ccccc}
\hline Specimen & 4C & 4C5S & 7C & 7C5S \\
\hline $\bar{L}(\mu \mathrm{m})$ & 2.94 & 3.34 & 1.88 & 2.29 \\
$\bar{W}(\mu \mathrm{m})$ & 0.86 & 0.87 & 0.32 & 0.43 \\
$\bar{R}$ & 3.41 & 3.83 & 5.88 & 5.37 \\
\hline
\end{tabular}

distribution with the length covers from 2 to $8 \mu \mathrm{m}$ and the width in the range of $0.5-1.5 \mu \mathrm{m}$. And the aspect ratio is also larger than that of $4 \mathrm{C}$.

To further understand the microstructure with a bimodal grain size distribution caused by the heterogeneous nucleation of $\mathrm{Li}_{2} \mathrm{Si}_{2} \mathrm{O}_{5}$ crystal seeds, a specimen of $4 \mathrm{C} 5 \mathrm{~S}$ was subjected to TEM investigation. The bright field TEM micrographs and their related electron diffraction patterns are shown in Fig. 6. In Fig. 6(a), it shows a large crystal with the length up to $\sim 6$ $\mu \mathrm{m}$ and some smaller grains embedded in the glass matrix. The corresponding diffraction pattern of this large crystal in Fig. 6(b) reveals that the crystal was oriented with the [110] plane parallel to the beam direction. And based on that, the calibrated diffraction pattern matches that of a single crystalline $\mathrm{Li}_{2} \mathrm{Si}_{2} \mathrm{O}_{5}$ lattice. Thus, the TEM analysis confirmed that crystalline phase in sample $4 \mathrm{C} 5 \mathrm{~S}$ is $\mathrm{Li}_{2} \mathrm{Si}_{2} \mathrm{O}_{5}$. The diffraction pattern in Fig. 6(c) indicated that the matrix was amorphous. More often than not, the thinnest part collapsed dramatically if the focused electron beam was on (the region marked in red shown in Fig. 6(d)), indicating that the local heat was so high that the specimen was rapidly perforated. So the epitaxial growth mode of large crystals along the seeds has not been observed yet in the TEM investigation.

\section{4 Mechanical properties}

Figure 7 shows the relative density, three-point flexural strength, and fracture toughness of the $\mathrm{Li}_{2} \mathrm{Si}_{2} \mathrm{O}_{5}$ glass-ceramics with different compositions. It can be seen that the relative densities are all above $98.80 \%$, indicating the densification degree is very high. The relative density decreased with the addition of seeds and the highest relative density up to $99.72 \% \pm 0.09 \%$ was obtained in the $4 \mathrm{C}$ sample. The flexure strength of $4 \mathrm{C} 5 \mathrm{~S}, 7 \mathrm{C}$, and $7 \mathrm{C} 5 \mathrm{~S}$ samples are very close to each other, all of which are approximately $400 \mathrm{MPa}$. The lowest flexural strength of $356 \pm 11 \mathrm{MPa}$ was recorded for the $4 \mathrm{C}$ specimen. It can be concluded that by adding $5 \mathrm{wt} \%$ seeds, the strength of $4 \mathrm{C}$ glass system increased by $11 \%$ while that of $7 \mathrm{C}$ glass system was
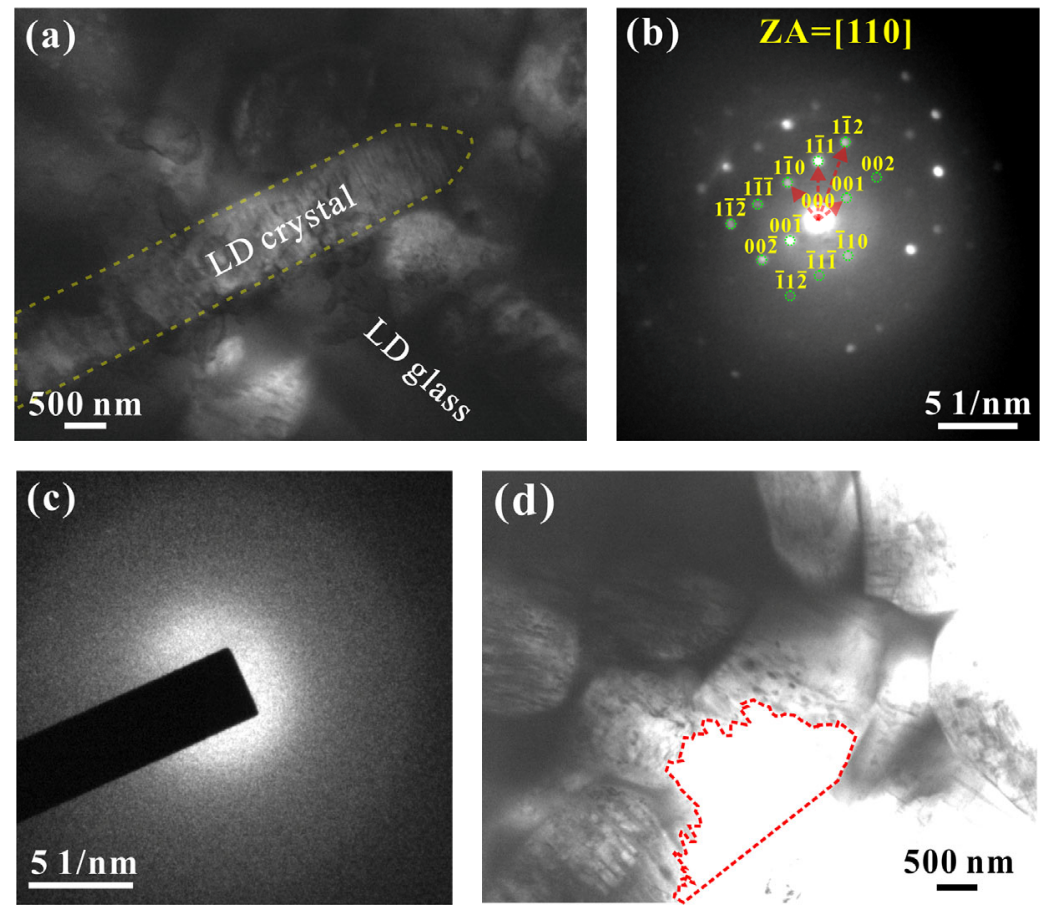

Fig. 6 TEM micrograph of the $\mathrm{Li}_{2} \mathrm{Si}_{2} \mathrm{O}_{5}$ glass-ceramics with $4 \mathrm{C} 5 \mathrm{~S}$ composition hot-pressed at $850{ }^{\circ} \mathrm{C}$ for $0.5 \mathrm{~h}$ : (a, d) bright field images; (b) corresponding electron diffraction pattern of the LD crystal in (a), indexed as the $\mathrm{Li}_{2} \mathrm{Si}_{2} \mathrm{O}_{5}$ phase in the [110] direction; (c) corresponding electron diffraction pattern of the LD glass in (a). 


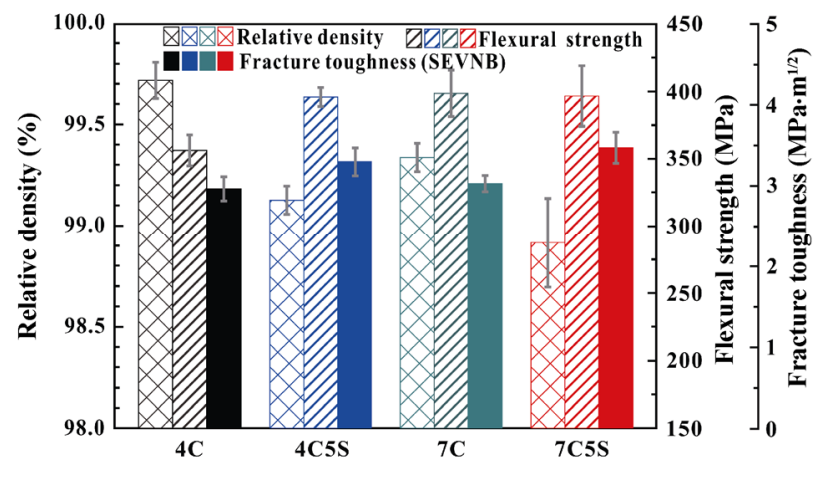

Fig. 7 Relative density, three-point flexural strength, and fracture toughness of the $\mathrm{Li}_{2} \mathrm{Si}_{2} \mathrm{O}_{5}$ glass-ceramics with different compositions.

not improved. As for the fracture toughness, the values of the both two glass compositions increased with the addition of $\mathrm{Li}_{2} \mathrm{Si}_{2} \mathrm{O}_{5}$ seeds. The toughness of $7 \mathrm{C} 5 \mathrm{~S}$ sample increased by $15 \%$ compared with $7 \mathrm{C}$, reaching the maximum value of $3.48 \pm 0.17 \mathrm{MPa} \cdot \mathrm{m}^{1 / 2}$, and that of $4 \mathrm{C} 5 \mathrm{~S}$ samples increased by $10 \%$ compared with $4 \mathrm{C}$, reaching $3.31 \pm 0.19 \mathrm{MPa} \cdot \mathrm{m}^{1 / 2}$.

\section{5 Translucency characteristics}

For dental restorative materials, in addition to the good mechanical properties, they also need to have a certain degree of translucency to simulate the gloss of natural teeth. Figure 8 compares the contrast ratio and appearances of the sintered samples with the commercially used IPS e.max (Ivoclar-Vivadent, casting-crystallization treatment at $850{ }^{\circ} \mathrm{C}$ for $1 \mathrm{~h}$ ). The contrast ratio of the specimens in this study was in a range of $0.47-0.68$. All the samples except the 7C5S specimen showed clearly underlying black-and-white backing, indicating a high visual degree of translucency.

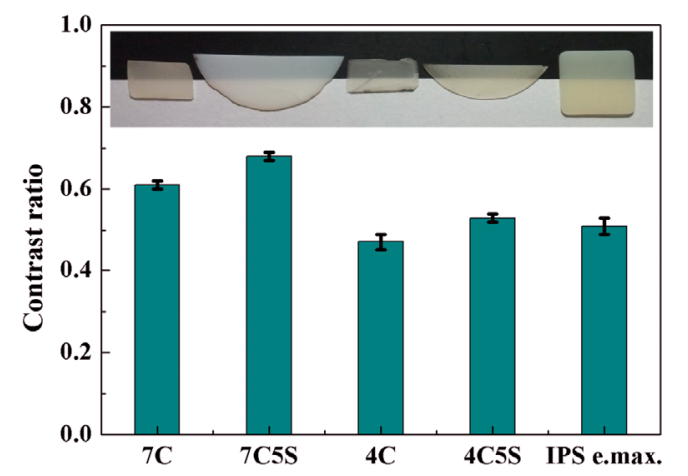

Fig. 8 Contrast ratio and appearance of the $\mathrm{Li}_{2} \mathrm{Si}_{2} \mathrm{O}_{5}$ glass-ceramics with different compositions compared with the IPS e.max specimen on a black-and-white backing with reflected light (the samples with $0.8 \mathrm{~mm}$ thickness were placed directly on the backing).

\section{Discussion}

\section{1 Crystalline phase and crystallinities}

Regardless of the different glass compositions with or without the seeds addition, $\mathrm{Li}_{2} \mathrm{Si}_{2} \mathrm{O}_{5}$ was detected as the only crystalline phase in Fig. 2. This is because the compositions of the original glass powders are very close to that of the added seeds, which satisfies the requirements of $\mathrm{Li}_{2} \mathrm{O}: \mathrm{SiO}_{2} \approx 1: 2.4$ to easily form $\mathrm{Li}_{2} \mathrm{Si}_{2} \mathrm{O}_{5}$ crystals without other impurities. The added $\mathrm{Li}_{2} \mathrm{Si}_{2} \mathrm{O}_{5}$ seeds could act as nuclei sites, so the simultaneous effect of surface nucleation from the glass powders and nucleation induced by the seeds increased the degree of crystallization. In addition, considering the the thermal history, there are three kinds of crystallization orders. The first is that only $\mathrm{Li}_{2} \mathrm{Si}_{2} \mathrm{O}_{5}$ crystals are formed while $\mathrm{Li}_{2} \mathrm{SiO}_{3}$ crystals do not appear [51]. However, Burgner et al. [52,53] questioned this view and tended to find that $\mathrm{Li}_{2} \mathrm{SiO}_{3}$ was not detected by XRD due to its short existence time. The second view is that the metastable $\mathrm{Li}_{2} \mathrm{SiO}_{3}$ could be firstly precipitated from the parent glass at low temperature $\left(\sim 650{ }^{\circ} \mathrm{C}\right)$, which provides heterogeneous nucleation sites for $\mathrm{Li}_{2} \mathrm{Si}_{2} \mathrm{O}_{5}$. At high temperature $\left(\sim 820{ }^{\circ} \mathrm{C}\right), \mathrm{Li}_{2} \mathrm{SiO}_{3}$ crystals react with the glassy matrix to form $\mathrm{Li}_{2} \mathrm{Si}_{2} \mathrm{O}_{5}$ as the following equation $[4,23,48,54,55]$ :

$$
\mathrm{Li}_{2} \mathrm{SiO}_{3} \text { (crystal) }+\mathrm{SiO}_{2} \text { (glass) }=\mathrm{Li}_{2} \mathrm{Si}_{2} \mathrm{O}_{5} \text { (crystal) }
$$

The third point is that $\mathrm{Li}_{2} \mathrm{SiO}_{3}$ and $\mathrm{Li}_{2} \mathrm{Si}_{2} \mathrm{O}_{5}$ nucleate at the same time firstly, and at about $620-770{ }^{\circ} \mathrm{C}$, $\mathrm{Li}_{2} \mathrm{SiO}_{3}$ crystals grow faster to the maximum while $\mathrm{Li}_{2} \mathrm{Si}_{2} \mathrm{O}_{5}$ crystals hardly grow. When the temperature reaches $790-850{ }^{\circ} \mathrm{C}, \mathrm{Li}_{2} \mathrm{SiO}_{3}$ crystals decompose and react with $\mathrm{SiO}_{2}$ to form rod-shaped interlocking $\mathrm{Li}_{2} \mathrm{Si}_{2} \mathrm{O}_{5}$ crystals $[42,43,56]$. The latter two kinds of crystalization mechanisms are more convincing now and what can be agreed is that the metastable phase of $\mathrm{Li}_{2} \mathrm{SiO}_{3}$ exists. Whether it nucleates first or simultaneously with $\mathrm{Li}_{2} \mathrm{Si}_{2} \mathrm{O}_{5}$, the growth of $\mathrm{Li}_{2} \mathrm{Si}_{2} \mathrm{O}_{5}$ crystal always involves the solid-state reaction between $\mathrm{Li}_{2} \mathrm{SiO}_{3}$ and $\mathrm{SiO}_{2}$. Nevertheless, for multi-component LD glasses, nucleation and crystal phase formation is also largely affected by the additives to glasses. In 7C LD glass, the addition of $\mathrm{P}_{2} \mathrm{O}_{5}$ is generally agreed that promotes phase separation so that the Li-rich and Si-rich phases formed, and $\mathrm{P}_{2} \mathrm{O}_{5}$ react with $\mathrm{Li}_{2} \mathrm{O}$ in the $\mathrm{Li}$-rich regions to form the $\mathrm{Li}_{3} \mathrm{PO}_{4}$ crystal nuclei, which act as nucleation sites. $\mathrm{Li}_{2} \mathrm{SiO}_{3}$ and $\mathrm{Li}_{2} \mathrm{Si}_{2} \mathrm{O}_{5}$ crystals can be obtained via epitaxial growth on $\mathrm{Li}_{3} \mathrm{PO}_{4}$ crystals [57]. As for $\mathrm{ZrO}_{2}$, if it is 
precipitated as a $\mathrm{ZrO}_{2}$ crystalline phase, it acts as a nucleating agent for $\mathrm{Li}_{2} \mathrm{Si}_{2} \mathrm{O}_{5}$ phase [42,58]. In our work, however, $\mathrm{ZrO}_{2}$ crystallites were not detected from the glassy matrix during the crystallization process as many researches reported $[4,59,60]$. So the nucleating role of $\mathrm{ZrO}_{2}$ is still not completely revealed. As to the $\mathrm{Al}_{2} \mathrm{O}_{3}$ component, it does not participate in the crystallization processes, but is located in a fourcoordinate network-forming species in the amorphous matrix [61], greatly decreasing the immiscibility trends in the $\mathrm{Li}_{2} \mathrm{O}-\mathrm{SiO}_{2}$ system. The addition of $\mathrm{K}_{2} \mathrm{O}$ to the parent glass leads to increasing the mean droplet size and their distribution density due to a decreasing energy barrier towards phase separation caused by the lowering of glass melt viscosity. $\mathrm{K}_{2} \mathrm{O}$-rich glasses suppress the crystallization of $\mathrm{Li}_{2} \mathrm{Si}_{2} \mathrm{O}_{5}$ and promot the formation of $\mathrm{Li}_{2} \mathrm{SiO}_{3}$ [44]. $\mathrm{La}_{2} \mathrm{O}_{3}$ leads to the effect that decreasing the nucleation rate by three orders of magnitude as well as increasing the induction time by one order of magnitude. Consequently, considering the same $\mathrm{SiO}_{2} / \mathrm{Li}_{2} \mathrm{O}$ ratio and thermal history, it can be concluded that in the compositions of $4 \mathrm{C}$ and $7 \mathrm{C}$ glasses, $\mathrm{P}_{2} \mathrm{O}_{5}$ is the main additive which causes the difference of crystallization mechanism between them. In the $4 \mathrm{C}$ glass without $\mathrm{P}_{2} \mathrm{O}_{5}$, only the surface nucleation of the powder dominates. So the crystallinities of 7C and 7C5S were higher than that of $4 \mathrm{C}$ and $4 \mathrm{C} 5 \mathrm{~S}$, respectively. It is worth noting that the crystallinity of $4 \mathrm{C} 5 \mathrm{~S}(65.7 \% \pm 2.6 \%)$ is higher than that of $7 \mathrm{C}(61.1 \% \pm 1.9 \%)$, which means that the seeds can completely replace the nucleating agent of $\mathrm{P}_{2} \mathrm{O}_{5}$ in promoting crystallization of the glass powder without nucleating agent, and the effect is even better.

\section{2 Microstructure}

The addition of $\mathrm{P}_{2} \mathrm{O}_{5}$ in $7 \mathrm{C}$ glass as the nucleating agent can promote the nucleation and increase the nucleation number, but cause a decrease in the linear growth rate of crystals [23]. Therefore, the grain size of $7 \mathrm{C}$ and $7 \mathrm{C} 5 \mathrm{~S}$ samples decreased. While in the $4 \mathrm{C}$ glass powder without $\mathrm{P}_{2} \mathrm{O}_{5}$, the mechanism of phase separation nucleation is eliminated so that the nucleation rate decreased resulting in an increase in the grain size of $\mathrm{Li}_{2} \mathrm{Si}_{2} \mathrm{O}_{5}$ crystals, especially in the direction of width. Actually $\mathrm{Li}_{2} \mathrm{Si}_{2} \mathrm{O}_{5}$ crystal is layered silicate structure, due to its higher growth rate along the $c$-axis direction, "long flake" grains piled up layer by layer so that the anisotropic rod-shaped morphology was formed [57]. In the $4 \mathrm{C}$ and $4 \mathrm{C} 5 \mathrm{~S}$ samples, the number of layers in the width direction increased. Consequently, the lamellar morphology was more obvious and the aspect ratio decreased. While for the $7 \mathrm{C}$ glass already containing $\mathrm{P}_{2} \mathrm{O}_{5}$, by adding seeds increased the nuclei number and the nucleis will grow in competition with each other, which is not conducive to the formation of large size grains. Therefore it can be concluded that the addition of $\mathrm{Li}_{2} \mathrm{Si}_{2} \mathrm{O}_{5}$ seeds is more effective for improving the microstructure of the nucleating agent-free glass. The TEM observation of 4C5S in Fig. 6 is consistent with the EBSD observation on the microstructure (the inset of Fig. 5(b)), and it is believed that such a microstructure consisted with large crystals induced by seeds embedded in small crystals may contribute to the enhancement of mechanical properties especially the fracture toughness.

\section{3 Densification}

The high density in powder sintered glass-ceramics played an important role in the improvement of mechanical properties and translucency. For the sintering of glass-ceramics, both the crystallization and the densification processes tend to meet the simultaneous motivation to decrease the free energy of glass powder [23]. The relative density decreased with the addition of seeds, which is due to the fact that on one hand, the crystalline phase increases the viscosity of the glass system so that hinders the flow of liquid phase in the sintering process to make the pore difficult to drain out. On the other hand, seeds promoted the nucleation and increased the crystallinities as shown in Fig. 3(b), leading to a high viscosity that hinders densification. Moreover, the relative density of $4 \mathrm{C}$ and $4 \mathrm{C} 5 \mathrm{~S}$ were higher than that of $7 \mathrm{C}$ and $7 \mathrm{C} 5 \mathrm{~S}$, respectively. It is because the nucleating agent of $\mathrm{P}_{2} \mathrm{O}_{5}$ in the $7 \mathrm{C}$ glass composition could promote phase separation nucleation and increase the crystallinities. Consequently, it can be concluded that the variation of relative density was closely related with the crystallinity; the higher the crystallinity, the lower the relative density.

\section{4 Mechanical properties}

Besides the higher relative density, improvement of the mechanical properties of the glass-ceramics can also be obtained with the higher crystallinity and the appropriate morphology of precipitated crystals $[4,62,63]$. From the above we can conclude that the mechanical properties are improved even when the density decreased with the addition of seeds, indicating the unfavorable influence 
of seeds on the densification can be minimized and made up by microstructure adjustment. For the $4 C$ LD glass, because of its dependence only on surface nucleation, its crystallinity is not high. Moreover, the grain size distribution is concentrative and the aspect ratio is small (Fig. 4 and Fig. 5), which cannot effectively prevent the crack propagation. The effect of these factors is that despite having a high relative density, the strength and fracture toughness of $4 \mathrm{C}$ specimen are not that ideal. By contrast, the increased strength of $4 \mathrm{C} 5 \mathrm{~S}$ specimen was mainly due to its increased crystallinity and higher aspect ratio of crystals. Because the thermal expansion coefficient of $\mathrm{Li}_{2} \mathrm{Si}_{2} \mathrm{O}_{5}$ crystalline phase is larger than that of the glass matrix, and thereby the crystals could develop a significant residual compressive stress in the surface of the glass during the cooling process, which strengthens the glass-ceramics [57]. The higher the crystallinity, the more obvious the strengthening effect is. The increased fracture toughness of $4 \mathrm{C} 5 \mathrm{~S}$ sample might be related to the bimodal grain size distribution and large rod-like grains, which was ascribed to grain bridging and crack deflection. As for the 7C specimen, the high crystallinity, small grain size, and large aspect ratio contributed to the excellent mechanical properties. When seeds are added, the density decreased but the crystallinity increased, making the flexure strength remains unchanged. And appearance of few large grains can effectively improve the fracture toughness.

\section{5 Translucency characteristics}

It is reported that the translucency of glass-ceramics is highly dependent on light scattering, and is closely related to the type and the size of the precipitated crystals, the crystallinity, and the porosity [4]. For $\mathrm{Li}_{2} \mathrm{Si}_{2} \mathrm{O}_{5}$ glass-ceramics, the refractive index of the crystalline phase and the parent glass are 1.55 and 1.50 [21], respectively, which are very close to each other. The grains size of the samples obtained in this study are all larger than $1 \mu \mathrm{m}$, it is beyond the range of strong light scattering $(0.39-0.78 \mu \mathrm{m})$, so the scattering effect of the type and size of crystals could be negligible [4]. Therefore, the porosity and crystallinity are the main factors affecting the translucency. The 7C5S sample shows a low relative density $(98.92 \% \pm 0.22 \%)$ and a high crystallinity up to $71.9 \% \pm 1.5 \%$, which means the pores become the strong light scattering centers and the glass phase does not meet the requirement (30-40 vol $\%$ ) for dental restorative glass-ceramics $[4,21]$. Thus, its translucency is poor. By contrast, owing to the higher relative density $(>99.10 \%)$ and lower crystallinity $(<66 \%)$, the other three groups of samples show a high translucency and their appearance is very close to the IPS e.max. From them we can clearly see the black and white background, and also they have a certain shading ability, similar to many dental restorative materials reported in the literature [7,21].

\section{6 Performance comparison}

Table 4 shows a comparison of the reported properties of lithium disilicate glass-ceramics and the results of the current study. It can be seen that different preparation methods lead to different results. The comprehensive properties in this study was comparable to the heat

\begin{tabular}{|c|c|c|c|c|}
\hline Author & Processing & Flexural strength $(\mathrm{MPa})$ & Fracture toughness $\left(\mathrm{MPa} \cdot \mathrm{m}^{1 / 2}\right)$ & Translucency \\
\hline Our work & Conventional hot-pressing technology & $\sigma=396 \pm 7$ (three-point) & $K_{\mathrm{IC}}=3.31 \pm 0.19(\mathrm{SEVNB})$ & $\begin{array}{c}\mathrm{CR}=0.47 \pm 0.02 \\
(0.8 \mathrm{~mm} \text { thickness })\end{array}$ \\
\hline Ref. [7] & IPS e.max & $\sigma=462 \pm 15$ (four-point) & $\begin{array}{c}K_{\mathrm{IC}}=3.1 \pm 0.2 \\
\text { (Double-torsion technique) }\end{array}$ & $\begin{array}{c}\mathrm{CR}=0.28 \pm 0.01 \\
(0.5 \mathrm{~mm} \text { thickness })\end{array}$ \\
\hline Ref. [10] & Conventional hot-pressing technology & $\sigma=340 \pm 38$ (three-point) & $K_{\mathrm{IC}}=3.5 \pm 0.3(\mathrm{SENB})$ & - \\
\hline Ref. [5] & Melting and two-stage heat treatment & $\sigma=562 \pm 107$ (three-point) & $K_{\mathrm{IC}}=3.5 \pm 0.1(\mathrm{SENB})$ & - \\
\hline Ref. [23] & Conventional hot-pressing technology & $\sigma=290 \pm 10$ (three-point) & $K_{\mathrm{IC}}=3.3 \pm 0.1(\mathrm{SENB})$ & - \\
\hline Ref. [27] & Heat-pressed + two-stage heat treatment & $\sigma=308 \pm 25$ (three-point) & - & $\begin{array}{c}\mathrm{TP}=21.2 \pm 0.4 \\
(0.5 \mathrm{~mm} \text { thickness })\end{array}$ \\
\hline Ref. [17] & Heat pressing LD GCs & $\sigma=303 \pm 49$ (three-point) & $K_{\mathrm{IC}}=3.0 \pm 0.65$ (indentation method) & - \\
\hline Ref. [64] & Heat pressing IPS Empress 2 & $\sigma=400 \pm 40$ (three-point) & $K_{\mathrm{IC}}=3.3 \pm 0.3(\mathrm{SENB})$ & $\mathrm{CR}=0.55(1 \mathrm{~mm}$ thickness $)$ \\
\hline Ref. [4] & Melting and two-stage heat treatment & $\sigma=310($ three-point $)$ & - & $\begin{array}{c}\mathrm{CR}=0.51 \\
(0.5 \mathrm{~mm} \text { thickness })\end{array}$ \\
\hline
\end{tabular}

SENB: single edge notched beam; TP: translucency parameter; CR: contrast ratio. 
pressing IPS Empress 2 reported by Hölland et al. [64], but better than other listed materials especially the hot-pressing sintered ones. The point is that compared with other methods, it is easier to add pigments to the glass powder during sintering, which can impart the end product with tooth-like optical properties. In addition, from the energy saving point of view, it is helpful to reduce the melting temperature of the glass system without adding the refractory nucleating agents. Consequently, the seeds were demonstrated to have great potential for improving the properties of glassceramics, and the sintered $4 \mathrm{C} 5 \mathrm{~S}$ specimen features a high potential as dental restorative materials.

\section{Conclusions}

High-performance $\mathrm{Li}_{2} \mathrm{Si}_{2} \mathrm{O}_{5}$ glass-ceramics were successfully hot-pressed by adding $\mathrm{Li}_{2} \mathrm{Si}_{2} \mathrm{O}_{5}$ crystal seeds to different two glass compositions. After adding seeds, the crystallinity increased, the relative density decreased, and the samples showed bimodal microstructures in which some large elongated $\mathrm{Li}_{2} \mathrm{Si}_{2} \mathrm{O}_{5}$ grains with high aspect ratio epitaxially grew along the seeds, and small grains directly crystallized from the parent glass powder. The role of heterogeneous nucleation by seeds was more effective in the $4 \mathrm{C}$ glass powder, making the grain size distribution of $4 \mathrm{C} 5 \mathrm{~S}$ sample more dispersed. Due to this microstructure, the high crystallinity, and the proper content of glass phase, the 4C5S specimen demonstrated the best comprehensive properties with a good flexural strength $(396 \pm 7 \mathrm{MPa})$, improved fracture toughness $\left(3.31 \pm 0.19 \mathrm{MPa} \cdot \mathrm{m}^{1 / 2}\right)$, and comparable translucency as IPS e.max. The highperformance glass-ceramics with seeds are promising for dental restorative applications especially three-unit posterior bridges, and offer a novel route for preparing toughened glass-ceramics without sacrifice other properties.

\section{Acknowledgements}

This work was supported by the National Natural Science Foundation of China (Grant Nos. 51702193 and 51502165), the General Project in Industrial Area of Shaanxi Province (Grant No. 2020GY-281), the Natural Science Foundation of Shaanxi Provincial Department of Education (Grant No. 20JK0525), the Shaanxi Provincial Education Department serves Local Scientific Research Plan (Grant No. 20JC008), and the Scientific Research Fund of Shaanxi University of Science \& Technology (Grant No. BJ16-20 and BJ16-21).

\section{References}

[1] Thieme K, Avramov I, Rüssel C. The mechanism of deceleration of nucleation and crystal growth by the small addition of transition metals to lithium disilicate glasses. Sci Rep 2016, 6: 25451.

[2] Gaddam A, Fernandes HR, Tulyaganov DU, et al. Role of manganese on the structure, crystallization and sintering of non-stoichiometric lithium disilicate glasses. Rsc $A d v 2014$, 4: 13581-13592.

[3] Zhao T, Qin Y, Wang B, et al. Improved densification and properties of pressureless-sintered lithium disilicate glass-ceramics. Mat Sci Eng A 2015, 620: 399-406.

[4] Wang F, Gao J, Wang H, et al. Flexural strength and translucent characteristics of lithium disilicate glass-ceramics with different $\mathrm{P}_{2} \mathrm{O}_{5}$ content. Mater Des 2010, 31: 3270-3274.

[5] Huang SF, Li Y, Wei SH, et al. A novel high-strength lithium disilicate glass-ceramic featuring a highly intertwined microstructure. J Eur Ceram Soc 2017, 37: 1083-1094.

[6] Wen LE, Roberts HW, Platt JA, et al. Microstructural evolution and physical behavior of a lithium disilicate glass-ceramic. Dent Mater 2015, 31: 928-940.

[7] Zhang F, Reveron H, Spies BC, et al. Trade-off between fracture resistance and translucency of zirconia and lithium-disilicate glass ceramics for monolithic restorations. Acta Biomater 2019, 91: 24-34.

[8] Tinschert J, Natt G, Mautsch W, et al. Fracture resistance of lithium disilicate-, alumina-, and zirconia-based three-unit fixed partial dentures: A laboratory study. Int J Prosthodont 2001, 14: 231-238.

[9] Harada K, Raigrodski AJ, Chung KH, et al. A comparative evaluation of the translucency of zirconias and lithium disilicate for monolithic restorations. J Prosthet Dent 2016, 116: $257-263$.

[10] Huang X, Zheng X, Zhao G, et al. Microstructure and mechanical properties of zirconia-toughened lithium disilicate glass-ceramic composites. Mater Chem Phys 2014, 143: 845-852.

[11] Thieme K, Ruessel C. Nucleation and growth kinetics and phase analysis in zirconia-containing lithium disilicate glass. J Mater Sci 2015, 50: 1488-1499.

[12] Schweiger M, Frank M, Von Clausbruch SC, et al. Microstructure and properties of a composite system for dental applications composed of glass-ceramics in the $\mathrm{SiO}_{2}-\mathrm{Li}_{2} \mathrm{O}-\mathrm{ZrO}_{2}-\mathrm{P}_{2} \mathrm{O}_{5}$ system and $\mathrm{ZrO}_{2}$-ceramic (TZP). $J$ Mater Sci 1999, 34: 4563-4572.

[13] Elsaka SE, Elnaghy AM. Mechanical properties of zirconia reinforced lithium silicate glass-ceramic. Dent Mater 2016, 32: 908-914. 
[14] Bergamo ETP, Bordin D, Ramalho IS, et al. Zirconiareinforced lithium silicate crowns: Effect of thickness on survival and failure mode. Dent Mater 2019, 35: 1007-1016.

[15] Zhang NZ, Anusavice KJ. Effect of alumina on the strength, fracture toughness, and crystal structure of fluorcanasite glass-ceramics. J Am Ceram Soc 1999, 82: 2509-2513.

[16] Tzeng JM, Duh JG, Chung $\mathrm{KH}$, et al. $\mathrm{Al}_{2} \mathrm{O}_{3^{-}}$and $\mathrm{ZrO}_{2}$-modified dental glass ceramics. J Mater Sci 1993, 28 : 6127-6135.

[17] Guazzato M, Albakry M, Ringer SP, et al. Strength, fracture toughness and microstructure of a selection of all-ceramic materials. Part I. Pressable and alumina glass-infiltrated ceramics. Dent Mater 2004, 20: 441-448.

[18] Kotoul M, Pokluda J, Šandera P, et al. Toughening effects quantification in glass matrix composite reinforced by alumina platelets. Acta Mater 2008, 56: 2908-2918.

[19] Xia L, Wang XY, Wen GW, et al. Influence of brick pattern interface structure on mechanical properties of continuous carbon fiber reinforced lithium aluminosilicate glass-ceramics matrix composites. J Eur Ceram Soc 2012, 32: 409-418.

[20] Sarno RD, Tomozawa M. Toughening mechanisms for a zirconia-lithium aluminosilicate glass-ceramic. J Mater Sci 1995, 30: 4380-4388.

[21] Heffernan MJ, Aquilino SA, Diaz-Arnold AM, et al. Relative translucency of six all-ceramic systems. Part II: Core and veneer materials. J Prosthet Dent 2002, 88: $10-15$.

[22] Gonzaga CC, Okada CY, Cesar PF, et al. Effect of processing induced particle alignment on the fracture toughness and fracture behavior of multiphase dental ceramics. Dent Mater 2009, 25: 1293-1301.

[23] Wen G, Zheng X, Song L. Effects of $\mathrm{P}_{2} \mathrm{O}_{5}$ and sintering temperature on microstructure and mechanical properties of lithium disilicate glass-ceramics. Acta Mater 2007, 55 : 3583-3591.

[24] Denry IL, Holloway JA. Effect of post-processing heat treatment on the fracture strength of a heat-pressed dental ceramic. J Biomed Mater Res Part B: Appl Biomater 2004, 68B: 174-179.

[25] Albakry M, Guazzato M, Swain MV. Influence of hot pressing on the microstructure and fracture toughness of two pressable dental glass-ceramics. $J$ Biomed Mater Res Part B: Appl Biomater 2004, 71B: 99-107.

[26] Yuan K, Wang F, Gao J, et al. Effect of zircon-based tricolor pigments on the color, microstructure, flexural strength and translucency of a novel dental lithium disilicate glass-ceramic. J Biomed Mater Res Part B: Appl Biomater 2014, 102: 98-107.

[27] Yuan K, Wang F, Gao J, et al. Effect of sintering time on the microstructure, flexural strength and translucency of lithium disilicate glass-ceramics. J Non-Cryst Solids 2013, 362: 7-13

[28] Shan ZJ, Liu JX, Shi F, et al. A new strengthening theory for improving the fracture strength of lithium disilicate glass-ceramics by introducing $\mathrm{Rb}$ or Cs ions. J Non-Cryst Solids 2018, 481: 479-485.

[29] Shan ZJ, Liu JX, Liu M, et al. Surface strengthening of lithium disilicate glass-ceramic by ion-exchange using $\mathrm{Rb}$, Cs nitrates. Ceram Int 2018, 44: 12466-12471.

[30] Zheng X, Wen G, Song L, et al. Effects of $\mathrm{P}_{2} \mathrm{O}_{5}$ and heat treatment on crystallization and microstructure in lithium disilicate glass ceramics. Acta Mater 2008, 56: 549-558.

[31] Molla AR, Chakradhar RPS, Kesavulu CR, et al. Microstructure, mechanical, EPR and optical properties of lithium disilicate glasses and glass-ceramics doped with $\mathrm{Mn}^{2+}$ ions. J Alloys Compd 2012, 512: 105-114.

[32] Thompson JY, Anusavice KJ, Balasubramaniam B, et al. Effect of micmcracking on the fracture toughness and fracture surface fractal dimension of lithia-based glass-ceramics. J Am Ceram Soc 1995, 78: 3045-3049.

[33] Zhao T, Li AJ, Qin Y, et al. Influence of $\mathrm{SiO}_{2}$ contents on the microstructure and mechanical properties of lithium disilicate glass-ceramics by reaction sintering. J Non-Cryst Solids 2019, 512: 148-154.

[34] Zhao T, Qin Y, Zhang P, et al. High-performance, reaction sintered lithium disilicate glass-ceramics. Ceram Int 2014, 40: $12449-12457$.

[35] Hirao K, Nagaoka T, Brito ME, et al. Microstructure control of silicon nitride by seeding with rodlike $\beta$-silicon nitride particles. J Am Ceram Soc 1994, 77: 1857-1862.

[36] Pyzik AJ, Beaman DR. Microstructure and properties of self-reinforced silicon nitride. J Am Ceram Soc 1993, 76: 2737-2744.

[37] Yoshizawa YI, Toriyama M, Kanzaki S. Preparation of high fracture toughness alumina sintered bodies from bayer aluminum hydroxide. J Ceram Soc Jpn 1998, 106: 1172-1177.

[38] Chen IW, Rosenflanz A. A tough SiAlON ceramic based on $\alpha-\mathrm{Si}_{3} \mathrm{~N}_{4}$ with a whisker-like microstructure. Nature 1997 , 389: 701-704.

[39] Peillon FC, Thevenot F. Microstructural designing of silicon nitride related to toughness. J Eur Ceram Soc 2002, 22: 271-278.

[40] Becher PF, Hsueh CH, Angelini P, et al. Toughening behavior in whisker-reinforced ceramic matrix composites. J Am Ceram Soc 1988, 71: 1050-1061.

[41] Wang B, Yang J, Guo R, et al. Microstructure and property enhancement of silicon nitride-barium aluminum silicate composites with $\beta-\mathrm{Si}_{3} \mathrm{~N}_{4}$ seed addition. J Mater Sci 2009, 44: 1351-1356.

[42] Höland W, Apel E, van't Hoen C, et al. Studies of crystal phase formations in high-strength lithium disilicate glass-ceramics. J Non-Cryst Solids 2006, 352: 4041-4050.

[43] Soares PC, Zanotto ED, Fokin VM, et al. TEM and XRD study of early crystallization of lithium disilicate glasses. $J$ Non-Cryst Solids 2003, 331: 217-227.

[44] Fernandes HR, Tulyaganov DU, Goel A, et al. Effect of $\mathrm{K}_{2} \mathrm{O}$ on structure-property relationships and phase transformations in $\mathrm{Li}_{2} \mathrm{O}-\mathrm{SiO}_{2}$ glasses. $J$ Eur Ceram Soc 
2012, 32: 291-298.

[45] Thieme K, Rüssel C. Nucleation inhibitors-The effect of small concentrations of $\mathrm{Al}_{2} \mathrm{O}_{3}, \mathrm{La}_{2} \mathrm{O}_{3}$ or $\mathrm{TiO}_{2}$ on nucleation and crystallization of lithium disilicate. J Eur Ceram Soc 2014, 34: 3969-3979.

[46] Bischoff C, Eckert H, Apel E, et al. Phase evolution in lithium disilicate glass-ceramics based on non-stoichiometric compositions of a multi-component system: Structural studies by ${ }^{29} \mathrm{Si}$ single and double resonance solid state NMR. Phys Chem Chem Phys 2011, 13: 4540-4551.

[47] Apel E, van't Hoen C, Rheinberger V, et al. Influence of $\mathrm{ZrO}_{2}$ on the crystallization and properties of lithium disilicate glass-ceramics derived from a multi-component system. J Eur Ceram Soc 2007, 27: 1571-1577.

[48] Fernandes HR, Tulyaganov DU, Goel IK, et al. Crystallization process and some properties of $\mathrm{Li}_{2} \mathrm{O}-\mathrm{SiO}_{2}$ glass-ceramics doped with $\mathrm{Al}_{2} \mathrm{O}_{3}$ and $\mathrm{K}_{2} \mathrm{O}$. J Am Ceram Soc 2008, 91: 3698-3703.

[49] Fernandes HR, Tulyaganov DU, Goel A, et al. Effect of $\mathrm{Al}_{2} \mathrm{O}_{3}$ and $\mathrm{K}_{2} \mathrm{O}$ content on structure, properties and devitrification of glasses in the $\mathrm{Li}_{2} \mathrm{O}-\mathrm{SiO}_{2}$ system. $J$ Eur Ceram Soc 2010, 30: 2017-2030.

[50] Lutterotti L, Matthies S, Wenk HR. MAUD: A friendly Java program for Material Analysis Using Diffraction. International Union of Crystallography Newsletter 1999, 21: $14-15$.

[51] Apel E, Höland W, Schweiger M, et al. Lithium disilicate glass ceramic. US Patent 7871948. 2011.

[52] Burgner LL, Weinberg MC, Lucas $\mathrm{P}$, et al. XRD investigation of metastable phase formation in $\mathrm{Li}_{2} \mathrm{O}-2 \mathrm{SiO}_{2}$ glass. J Non-Cryst Solids 1999, 255: 264-268.

[53] Burgner LL, Lucas $\mathrm{P}$, Weinberg MC, et al. On the persistence of metastable crystal phases in lithium disilicate glass. J Non-Cryst Solids 2000, 274: 188-194.

[54] Höland W, Rheinberger V, Schweiger M. Control of nucleation in glass ceramics. Phil Trans $R$ Soc A 2003, 361: $575-589$.

[55] Iqbal Y, Lee WE, Holland D, et al. Metastable phase formation in the early stage crystallisation of lithium disilicate glass. J Non-Cryst Solids 1998, 224: 1-16.

[56] Huang SF, Cao P, Li Y, et al. Nucleation and crystallization kinetics of a multicomponent lithium disilicate glass by in situ and real-time synchrotron X-ray diffraction. Cryst Growth Des 2013, 13: 4031-4038.
[57] Höland W, Beall GH. Glass-ceramic Technology. Hoboken, NJ, USA: John Wiley \& Sons, Inc., 2012.

[58] Huang SF, Zhang B, Huang ZH, et al. Crystalline phase formation, microstructure and mechanical properties of a lithium disilicate glass-ceramic. J Mater Sci 2013, 48: 251-257.

[59] Huang S, Huang Z, Gao W, et al. Trace phase formation, crystallization kinetics and crystallographic evolution of a lithium disilicate glass probed by synchrotron XRD technique. Sci Rep 2015, 5: 9159.

[60] Goharian P, Nemati A, Shabanian M, et al. Properties, crystallization mechanism and microstructure of lithium disilicate glass-ceramic. J Non-Cryst Solids 2010, 356: 208-214.

[61] Fernandes HR, Tulyaganov DU, Goel A, et al. Structural characterisation and thermo-physical properties of glasses in the $\mathrm{Li}_{2} \mathrm{O}-\mathrm{SiO}_{2}-\mathrm{Al}_{2} \mathrm{O}_{3}-\mathrm{K}_{2} \mathrm{O}$ system. $J$ Therm Anal Calorim 2011, 103: 827-834.

[62] Tulyaganov DU, Agathopoulos S, Kansal I, et al. Synthesis and properties of lithium disilicate glass-ceramics in the system $\mathrm{SiO}_{2}-\mathrm{Al}_{2} \mathrm{O}_{3}-\mathrm{K}_{2} \mathrm{O}-\mathrm{Li}_{2} \mathrm{O}$. Ceram Int 2009, 35: 3013-3019.

[63] Zhang JY, Zhan H, Fu ZY, et al. In-situ synthesis and sintering of mullite glass composites by SPS. $J$ Adv Ceram 2014, 3: 165-170.

[64] Höland W, Schweiger M, Frank M, et al. A comparison of the microstructure and properties of the IPS Empress ${ }^{\circledR} 2$ and the IPS Empress ${ }^{\circledR}$ glass-ceramics. $J$ Biomed Mater Res 2000, 53: 297-303.

Open Access This article is licensed under a Creative Commons Attribution 4.0 International License, which permits use, sharing, adaptation, distribution and reproduction in any medium or format, as long as you give appropriate credit to the original author(s) and the source, provide a link to the Creative Commons licence, and indicate if changes were made.

The images or other third party material in this article are included in the article's Creative Commons licence, unless indicated otherwise in a credit line to the material. If material is not included in the article's Creative Commons licence and your intended use is not permitted by statutory regulation or exceeds the permitted use, you will need to obtain permission directly from the copyright holder.

To view a copy of this licence, visit http://creativecommons.org/licenses/by/4.0/. 